\title{
BEyOND the FLIGHT FROM CONSTITUTIONAL Legalism: Rethinking the Politics of Social Policy Post-Charlottetown
}

\author{
Sujit Choudhry
}

\section{INTRODUCTION: THE FLIGHT FROM CONSTITUTIONAL LEGALISM}

A decade after the demise of the Charlottetown Accord in 1992, ${ }^{1}$ one of the most visible features of federal-provincial relations is the replacement of constitutional with non-constitutional policy instruments to secure many of the same ends - what I term the "flight from constitutional legalism." Instead of constitutional amendments, the instrument of choice is the non-legal, intergovernmental accord. The leading examples are the Social Union Framework Agreement ${ }^{2}$ and the Agreement on Internal Trade, ${ }^{3}$ which in differing levels of detail set out both a normative framework and an institutional architecture to manage the Social Union and the Economic Union, respectively.

Although this description is accurate, I argue, focusing on the Social Union, that it is radically incomplete in two respects. I suggest that the politics of social policy in the post-Charlottetown era are now somewhat broader in scope than they were before 1992, and encompass not just issues of substance, but issues of process as well, with the latter arguably assuming central importance. Moreover, I demonstrate that the shift to non-constitutional means should not obscure two facts. First, the law of the Constitution and constitutional litigation have played a limited role in the politics of social policy. Second, constitutional discourse outside the courts has been the primary vehicle for constitutional evolution. Indeed, the $S U F A$

Canada, Charlottetown Accord: Draft Legal Text (Ottawa: Queen's Printer, 1992).

2 Canada, A Framework to Improve the Social Union for Canadians - An Agreement between the Government of Canada and the Governments of the Provinces and Territories (4 February 1999), online: Government of Canada <socialunion.gc.ca/news/020499_e.html> [hereinafter SUFA]. Canada, Agreement on Internal Trade (Ottawa: Industry Canada, 1994) should, in this light, be interpreted as a constitutional policy instrument. Finally, I propose that, going forward, the courts should regard the shift from substance to process as a constitutional cue to play a limited but important role in the management of the Social Union.

The flight from constitutional legalism is a narrative that proceeds in a number of stages. First, it is a story of attempted constitutional amendment. On the social policy side, the central provision in both the Meech Lake ${ }^{4}$ and Charlottetown ${ }^{5}$ Accords was the proposed section 106A. That provision was designed to set up some constitutional restraints, presumably enforceable by the courts, on exercises of the federal spending power in areas of provincial jurisdiction. If adopted, section 106A would have given provinces the right to opt out with "reasonable compensation" from shared cost programs. However, the right to opt out only applied to those programs established after the provision came into force, and required provinces to operate a program that was "compatible with national objectives."

Canada, Constitutional Accord 1987 (Ottawa: Queen's Printer, 1987) at c. 7.

Supra note 1 at s. 16. The proposed language for s. 106A in the Accords was not entirely identical. Both Accords would have inserted the following provision into the Constitution Act, 1867: 106A (1) The Government of Canada shall provide reasonable compensation to the government of a province that chooses not to participate in a national shared-cost program that is established by the Government of Canada after the coming into force of this section in an area of exclusive provincial jurisdiction, if the province carries on a program or initiative that is compatible with the national objectives.

(2) Nothing in this section extends the legislative powers of the Parliament of Canada or of the legislatures of the provinces.

In addition, the Charlottetown Accord would have added the following sub-section:

(3) For greater certainty, nothing in this section affects the commitments of the Parliament and government of Canada set out in section 36 of the Constitution Act, 1982. 
Section 106A was attacked both by advocates and opponents of a strong federal presence in social policy, who fundamentally disagreed over how stringent the constraints it contained would be. To English Canadian nationalists like Deborah Coyne, section 106A would have opened the door to "checkerboard Canada," because it would have undermined both the national reach and uniform content of new federal social policy initiatives. To Quebec nationalists, however, section 106A did not go nearly far enough, not only because of the conditions attached to opting out, but also because it did not apply to direct federal transfers to individuals and institutions, either through direct grants or the tax system. ${ }^{6}$

This debate on the effects of the provision was never resolved, because neither the Meech Lake nor Charlottetown Accords were adopted. Thus, the second piece of the flight from constitutional legalism is constitutional failure - the failed attempts at constitutional reform in both the Quebec and Canada rounds. No doubt, the Accords failed because of disputes over their substance. However, another important cause of failure was the unforeseen interaction between the character of constitutional politics and the legal rules governing constitutional amendment. As Peter Russell has famously observed, the late 1980 s and early 1990 s marked the emergence of "mega-constitutional politics," whereby constitutional reform had to address either an extremely wide range of issues simultaneously, or none at all. ${ }^{7}$ As a consequence, both the Meech and Charlottetown Accords were packages that contained a large number of individual constitutional amendments which politically stood or fell together. The constitutional complication this created was that the various amendments triggered different amending formulas, whose requirements accordingly had to be met simultaneously. As a result, both Accords necessitated unanimous consent within three years of their

6 See generally K. Banting, "Political Meaning and Social Reform" in K.E. Swinton \& C.J. Rogerson, eds., Competing Constitutional Visions: the Meech Lake Accord (Toronto: Carswell, 1988) 163; R.W. Boadway, J.M. Mintz \& D.D. Purvis, "Economic Policy Implications of the Meech Lake Accord" in Swinton \& Rogerson, ibid., 225 at 229-32; D. Coyne, "The Meech Lake Accord and the Spending Power Proposals: Fundamentally Flawed" in M.D. Behiels, ed., The Meech Lake Primer: Conflicting Views of the 1987 Constitutional Accord (Ottawa: University of Ottawa Press, 1989) 245; and P. Fortin, "The Meech Lake Accord and The Federal Spending Power: A Good Maximin Solution" in Swinton \& Rogerson, ibid., 213.

P.H. Russell, Constitutional Odyssey: Can Canadians Become a Sovereign People?, 2d ed. (Toronto: University of Toronto Press, 1993). introduction..$^{8}$ In both cases, this was fatal. ${ }^{9}$ Moreover, the legal implications of mega-constitutional politics have effectively shut the door on comprehensive constitutional change in Canada.

Federal and provincial governments have accordingly searched for ways to achieve some of the goals set out in the Accords, but without recourse to constitutional amendment. This is the third component of the flight from constitutional legalism - the shift in instrument choice from constitutional amendments to other policy instruments. Harvey Lazar captures this change through the term "non-constitutional renewal."10 Interestingly, governments have eschewed legal means entirely, foregoing even statutes that could have given rise to legally enforceable obligations subject to the normal process of statutory amendment. The instrument of choice has been the intergovernmental agreement, which, as the Supreme Court of Canada held in the Reference re Canada Assistance Plan ${ }^{11}$ in 1991, is legally unenforceable. The most law-like of these agreements is the Agreement on Internal Trade, which both sets out substantive norms and creates institutional machinery for their enforcement with respect to the Economic Union. ${ }^{12}$ In the social policy context, nine provinces, the territories and the federal government signed the $S U F A$ in 1999, with Quebec declining to participate.

\section{SHIFTING FROM SUBSTANCE TO PROCESS}

This picture provides a reasonably good account of some of the salient features of federal-provincial

8 This was the result of the simultaneous operation of ss. 38 and 39 (requiring the passage of resolutions by Parliament and the legislative assemblies of two-thirds of the provinces representing at least fifty percent of the population within three years of the adoption of the resolution initiating the amending procedure) and s. 41 (requiring unanimous consent) of the Constitution Act, 1982, being Schedule B to the Canada Act 1982 (U.K.), 1982, c. 11.

9 K. Swinton, "Amending the Canadian Constitution: Lessons from Meech Lake" (1992) 42 U.T.L.J. 139.

10 H. Lazar, "Non-Constitutional Renewal: Toward a New Equilibrium in the Federation" in H. Lazar, ed., NonConstitutional Renewal (Kingston: Institute of Intergovernmental Relations, 1998) 3.

11 Reference re Canada Assistance Plan, [1991] 2 S.C.R. 525 [hereinafter CAP Reference]. The judgment is capable of alternative interpretations. For a lengthier discussion see S. Choudhry, "The Enforcement of the Canada Health Act" (1996) 41 McGill L.J. 461 at 503-505.

12 For a more detailed discussion of the Agreement on Internal Trade, see M.J. Trebilcock \& R. Behboodi, "The Canadian Agreement on Internal Trade: Retrospects and Prospects" in M.J. Trebilcock \& D. Schwanen, eds., Getting There: An Assessment of the Agreement on Internal Trade (Toronto: C.D. Howe Institute, 1995) 20. 
relations over the past decade. However, it is incomplete in two respects. First, it does not give sufficient emphasis to important changes in the content of the norms contained in federal-provincial initiatives since the demise of the Charlottetown Accord. To illustrate this shift, let us compare section 106A and the SUFA. The key provision in section 106A is the provincial right to exit with compensation. At the time that section 106A was proposed, neither of the statutes creating the legal framework for the principal federal shared-cost programs - the Canada Assistance Plan $A c t,{ }^{13}$ covering social assistance, and the Canada Health Act,${ }^{14}$ covering health care - granted provinces such a right. The effect of section 106A would have been to insert into each federal shared program a new condition that bound the federal government, and would have prevented it from operating as it had before. As such, section 106A would have constituted a substantive limit on federal jurisdiction. To be sure, there was considerable disagreement over how much of a constraint section 106A really would have been. This disagreement in large part turned on important textual ambiguities in the provision that likely made negotiated agreement possible, and implicitly but deliberately deferred important issues to subsequent constitutional litigation. For example, it was unclear whether changes to existing programs would make those programs "new," and hence trigger the right to opt out with compensation. Moreover, the extent to which a provincial program had to be "compatible with the national objectives" was also ambiguous. However, putting those points to one side, the goal behind section $106 \mathrm{~A}$ was clear.

The SUFA also contains provisions, found in article 5, governing the creation of shared cost programs. Like section 106A, article 5 creates a right to opt out with compensation, permitting provinces and territories that satisfy "Canada-wide objectives" to reinvest funds. That being said, article 5 differs from section 106A in several respects. Canada-wide objectives must be set by the federal government in collaboration with the provinces and territories, whereas section 106A would have permitted them to be set by the federal government unilaterally. Moreover, even though article 5 requires provinces to adhere to an "accountability framework," presumably to comply with national objectives, that framework is to be agreed to by both levels of government. Section 106A made no reference to an accountability framework, but it is a reasonable reading of the provision that the terms of such a framework would have been a matter for the federal government alone to determine. Most significantly, unlike section $106 \mathrm{~A}$, article 5 requires the

R.S.C. 1985 , c. C-1 [hereinafter $C A P$ ] R.S.C. 1985, c. C-6 [hereinafter $C H A]$. consent of the majority of provincial governments for the introduction of new shared cost programs.

What unites these provisions of article 5 is that they speak to issues of process. This theme runs throughout the $S U F A$. For example, article 5 also deals with direct federal spending, and prior to the introduction of new programs, requires the federal government to give provincial and territorial governments three months notice and to offer to consult with them. Article 4, entitled "Working in Partnership for Canadians," is also of considerable interest. Governments commit to "[u]ndertake joint planning," and to "[c]ollaborate on implementation of joint priorities" when appropriate. Moreover, recognizing that changes to social programs at one level of government often have spillover effects on programs operated by the other level of government (consider for instance, changes to eligibility rules and benefit levels for social assistance and unemployment insurance), governments agree to give notice prior to, and to consult regarding, such changes.

Finally, there is article 6, which deals with "Dispute Resolution and Avoidance." Presumably, this provision applies if consultation and collaboration have failed. Signatories commit themselves to "working collaboratively to avoid and resolve intergovernmental disputes." It appears that article 6 contemplates three types of processes: dispute avoidance, negotiation, and mediation. Dispute avoidance is encouraged "through information-sharing, joint planning, collaboration, advance notice and early consultation, and flexibility in implementation." Negotiation proceeds on the basis of joint fact-finding, which may be conducted by a third party, and which will be made public if one party so requests. In addition, negotiation may be accompanied by mediation. Again, mediation reports will be made public if one party so requests. Mechanisms for dispute resolution must respect a list of general principles: they have to be "simple, timely, efficient, effective and transparent," allow for the possibility of non-adversarial solutions, be appropriate for the specific sectors in which the disputes arise, and provide for the expert assistance of third parties.

I see at least two causes for this dramatic shift in the norms governing the Social Union from substantive to procedural. The first is deep provincial frustration over the circumstances surrounding the introduction in 1995 of the Canada Health and Social Transfer, ${ }^{15}$ which altered both the federal funding formula and levels of federal support for health care and social assistance. At

15 The Canada Health and Social Transfer [hereinafter CHST] was introduced through the Budget Implementation Act, 1995, S.C. 1995 , c. 17. 
that time, provinces accused the federal government of having acted without prior notice or consultation, let alone provincial consent, effectively shifting both the financial and political costs of federal deficit reduction onto provincial governments. Although the provinces did receive a quid pro quo, in the form of the elimination of all national standards for social assistance except the prohibition on minimum residency requirements, provincial bitterness remained, and placed in jeopardy the success of future federal policy activism. Moreover, by reducing the level of federal transfers, the CHST reduced the federal government's financial leverage and political capital, thereby diminishing its capacity for unilateralism going forward. The resistance of several provincial governments toward federal proposals for increased accountability for health care transfers is a recent and highly visible reflection of this legacy.

The second cause for this shift is ongoing provincial frustration with the enforcement of the national standards in the $C H A$. In many ways, this is puzzling, given that the $C H A$ is largely an unenforced statute. As I have argued in detail elsewhere, although monies have been withheld from provinces that permit user fees and extra-billing, the net amounts of such withheld funds are extremely small, and the federal government has never found a province to be in breach of the "big five" conditions of universality, comprehensiveness, accessibility, portability, and public administration, despite actual and alleged noncompliance with several of these criteria.${ }^{16}$ However, in those few cases in which the $C H A$ was enforced, the provinces complained of federal unilateralism. The Gimbel Eye Clinic dispute - in which Alberta complained that the federal government determined that the "facility fee" charged by a privately owned clinic providing publicly insured services was a user charge prohibited by the $C H A-$ is a good example. ${ }^{17}$ In the face of diminished federal financial contributions, provinces were unwilling to let the old rules of the game continue. Article 6 , by promoting dispute resolution and avoidance, speaks directly to that concern. Whereas the CHA locates the legal responsibility for interpreting and enforcing national standards with the federal government, ${ }^{18}$ article 6 seeks

16 For a review of the enforcement history of the $C H A$, see $\mathrm{S}$. Choudhry, "Bill 11, The Canada Health Act and the Social Union: The Need for Institutions" (2000) 38 Osgoode Hall L.J. 39 at 51-59. A recent newspaper report, based on a review of internal Health Canada documents, cites many instances of potential non-compliance: L. Priest, "List reveals provinces violated health act" Globe \& Mail (13 December 2002) A 1.

17 Discussed in Choudhry, ibid. at 54

18 CHA, supra note 14 at ss. 13-17 (governing national standards for which the decision to withhold funds is discretionary, not mandatory). to shift at least political responsibility to intergovernmental institutions that are not under the control of one level of government.

\section{THE IRRELEVANCE OF THE LEGAL CONSTITUTION AND CONSTITUTIONAL LITIGATION}

The idea of the flight from constitutional legalism implicitly suggests that the legal Constitution was an important factor in the politics of social policy prior to the Quebec and Canada rounds, and that the Meech Lake and Charlottetown Accords responded directly to dissatisfaction with the constitutional text and its interpretation by the courts. This is certainly how to read the various proposals to strengthen the Canadian Economic Union over the past two decades, particularly during the Patriation round. Those proposals responded to a profound sense of constitutional failure, attributable to both the text of the Constitution Act, 1867 and judicial interpretation of that document. ${ }^{19}$ However, it would be a serious misreading of our constitutional history to translate the politics of economic policy to the social policy context. In the growth and evolution of the Social Union, the legal Constitution has played a comparatively minor role, as have the courts.

The first thing to note is that notwithstanding the centrality of social policy to federal-provincial relations since the Second World War, the Constitution is largely silent on critical jurisdictional questions. Neither sections 91 nor 92 of the Constitution Act, 1867 contain explicit references to social assistance or health insurance. There is a good reason for this - as the Rowell-Sirois Commission noted, the welfare state was not within the contemplation of the framers of the Constitution in $1867 .{ }^{20}$ To be sure, as the welfare state has developed, the Constitution has been amended to assign jurisdiction over unemployment insurance, ${ }^{21}$ old age pensions, ${ }^{22}$ and supplementary and disability

19 Constitution Act, 1867 (U.K.), 30 \& 31 Vict., c. 3, reprinted in R.S.C. 1985, App. II, No. 5. I make this point in S. Choudhry, "Strengthening the Economic Union: the Charter and the Agreement on Internal Trade" (2002) 12 Constitutional Forum 112 .

20 Canada, Report of the Royal Commission on DominionProvincial Relations (Canada: Queen's Printer, 1940) (Chairs: N. Rowell \& J. Sirois).

${ }^{21}$ Supra note 19 at s. 91(2A), conferring power over unemployment insurance, was added by the Constitution Act, 1940 (U.K.), R.S.C. 1985, App. II, No. 28 following the Privy Council's decision in Canada (A.G.). v. Ontario (A.G.). (Unemployment Insurance), [1937] A.C. 355 [hereinafter Unemployment Insurance Reference].

22 Ibid., s. 94A, conferring power over old age pensions, was added by the Constitution Act, 1951 (U.K.), R.S.C. 1985, App. II, No. 35 . 
benefits. $^{23}$ However, none of these amendments textually entrenched jurisdiction over social assistance and health insurance, two of the principal areas of federal-provincial interaction. Nor did the Meech Lake and Charlottetown Accords expressly address the jurisdictional issue, even if only to clarify it.

In the absence of any clear direction in the constitutional text, it fell to the courts to assign jurisdiction through interpretation. In 1937, the Privy Council held in the Unemployment Insurance Reference $^{24}$ that the provinces had jurisdiction over all forms of social insurance, including health insurance. The following year, the Supreme Court held in the Adoption Reference ${ }^{25}$ that direct social service provision also lies within provincial jurisdiction. But in the Unemployment Insurance Reference, the Privy Council announced the existence of the federal spending power, and expressly referred to the power of the federal government to make its grants subject to conditions. Thus, notwithstanding its holding on jurisdiction, that judgment created the constitutional space for federal involvement, and set the stage for the centrality of shared cost statutes during the growth and expansion of the Social Union.

I think these rulings are highly questionable, both on the constitutional case law as it stood at the time, and even more so today. ${ }^{26}$ Yet notwithstanding my serious misgivings, it is undeniable that those judgments laid down the legal framework within which the politics of social policy have taken place. But interestingly, since the 1930 s, the courts have largely been non-participants in federal-provincial disputes in the social policy arena. This stands in marked contrast to the many areas of federal-provincial conflict in which the courts have been centrally involved - for example, natural resources,$^{27}$ environmental policy, ${ }^{28}$ and broadcasting, ${ }^{29}$ just to name a few. The absence of

23 Ibid., s. 94A was expanded to cover supplementary benefits including survivors' and disability benefits by the Constitution Act, 1964 (U.K.), R.S.C. 1985 App. II, No. 38.

24 Unemployment Insurance Reference, supra note 21.

25 Reference Re Adoption Act (Ontario), [1938] S.C.R. 398.

26 For an extended discussion, see S. Choudhry, "Recasting Social Canada: A Reconsideration of Federal Jurisdiction over Social Policy" (2002) 52 U.T.L.J. 163 at 166-98 [hereinafter "Recasting Social Canada"].

27 Central Canada Potash v. Saskatchewan, [1979] 1 S.C.R. 42; Canadian Industrial Gas \& Oil v. Saskatchewan, [1978] 2 S.C.R. 545; Reference Re Proposed Federal Tax on Exported Natural Gas, [1982] 1 S.C.R. 1004.

28 R. v. Crown Zellerbach, [1988] 1 S.C.R. 401; Friends of the Oldman River Society v. Canada (Minister of Transport), [1992] 1 S.C.R. 3; R. v. Hydro-Québec, [1997] 3 S.C.R. 213.

29 Capital Cities Communications v. Canadian Radio-Television Commission, [1978] 2 S.C.R. 141; Quebec (Public Service Board) v. Dionne, [1978] 2 S.C.R. 191; Quebec (A.G.) v. Kellogg's Co., [1978] 2 S.C.R. 211. social policy disputes from the courts is all the more striking when one considers that fundamental questions regarding the Canadian constitutional order, such as the patriation of the Constitution ${ }^{30}$ and the potential secession of Quebec,$^{31}$ have come before the Supreme Court. Social policy is conspicuous by its absence from the list, a point that the literature on judicial activism has surprisingly ignored.

The non-participation of the courts can be traced to the reluctance of governments to litigate social policy disputes, on the view that the potential risks of judicial intervention outweighed the potential benefits. The federal government was likely fearful that the courts would impose some limits on the conditions that could attach to grants, a point gestured to by the Privy Council $^{32}$ (albeit now seemingly abandoned by the Supreme Court). ${ }^{33}$ Conversely, the provinces other than Quebec wanted federal transfers to be unconditional, but feared that a Supreme Court ruling could legitimize intrusive conditions. Furthermore, Quebec's consistent demand - not for unconditional transfers, but rather for the right to opt out with compensation, for example through a tax point transfer to redress vertical fiscal imbalance - was unlikely to succeed in constitutional litigation. $^{34}$

Those few cases in which the courts did become involved stemmed from litigation launched by private parties. Some of these cases involved unsuccessful challenges to the Family Allowances Act, ${ }^{35}$ the precursor to the Canada Pension Plan, ${ }^{36}$ the Canada Home and Mortgage Corporation, ${ }^{37}$ and the whole edifice of shared cost programs in Winterhaven Stables v. Canada (A.G.). ${ }^{38}$ Two cases, which reached the Supreme Court, turned on the enforcement of the national standards spelled out in the Canada Assistance Plan, with the Court ruling that the CAP had not been breached. $^{39}$ The one intergovernmental dispute that came before the courts was the constitutional challenge to the "cap on CAP" (the CAP Reference) in which the Supreme Court held that the federal government had

Re Resolution to Amend the Constitution, [1981] 1 S.C.R. 753.

31 Reference Re Secession of Quebec, [1998] 2 S.C.R. 217 [hereinafter Secession Reference].

32 Unemployment Insurance Reference, supra note 21 at 367.

33 CAP Reference, supra note 11 at 567.

34 For a lengthier discussion, see "Recasting Social Canada," supra note 26 at 199 .

35 S.C. $1944-45$, c. 40 , as am. by S.C. 1946, c. 50, in Angers v. M.N.R., [1957] Ex. C.R. 83.

36 Porter v. Canada, [1965] 1 Ex. C.R. 200

37 Central Mortgage and Housing Corp. v. Co-op College Residences (1975), 13 O.R. (2d) 384 (C.A.).

38 (1988), 53 D.L.R. (4th) 413 (Alta. C.A.).

39 Finlay v. Canada (Minister of Finance), [1986] 2 S.C.R. 607 (standing); and Finlay v. Canada (Minister of Finance), [1993] 1 S.C.R. 1080 (merits). 
not breached its agreements with the provinces, and that even if it had, it had the legislative power to do so, since such agreements could not fetter parliamentary sovereignty.

However, the non-involvement of the courts and the legal Constitution does not mean that ideas associated with the Constitution did not matter. Indeed, provincial claims have often been framed in the language of jurisdiction, with federal initiatives often opposed by provinces not merely as being unwise on public policy grounds, but also as representing unconstitutional intrusions into spheres of exclusive provincial competence. Moreover, if one examines in detail the House of Commons debates surrounding the introduction of the Medical Care $A c t^{40}$ and the CHST, one sees Members of Parliament on both sides of these debates making a mixture of policy and constitutional arguments. $^{41}$

The presence of constitutional discourse in political arenas, along with the absence of court challenges to resolve jurisdictional disputes, invites differing explanations. From the vantage point of traditional, court-centered constitutional scholarship, the natural interpretation of this pattern of constitutional practice would be that political actors were grappling with the constitutional limits of their jurisdiction as laid down by the courts, as one would expect in a liberal democracy. In those areas where the legal position is unclear, political actors would rely on conflicting pieces of constitutional doctrine, engaging in what I term doctrinal politics.

To be sure, a lot of this has gone on. Political actors have explored the real tensions between different aspects of the legal framework governing federal involvement in the social policy arena - for example, the fact that the federal government lacks regulatory jurisdiction over social policy but may nonetheless lay down conditions that provinces must comply with to qualify for federal funding. However, I think there is more going on here, which students of constitutional theory would do well to study more closely. Rather than merely operating in the shadow of judicial doctrine, political actors have engaged in a process of constitutional interpretation. In the absence of judicial elaboration of the Constitution, the site for constitutional evolution of the legal framework governing social policy has been in politics. The politics of social policy, in other words, has been an arena for constitutional politics, and is an excellent

\footnotetext{
S.C. $1966-67$, c. 64

41 As detailed in "Recasting Social Canada," supra note 26 at 205-12.
}

example of constitutional discourse occurring outside of the courts.

At one level, recognizing the ability of political actors to achieve constitutional change without recourse to constitutional litigation and the courts is hardly an earth-shattering observation. Indeed, this is the whole idea behind the rules governing constitutional amendment, which, under the Canadian Constitution, do not explicitly assign any role to the courts. ${ }^{42}$ But given the non-viability of constitutional amendment over the past decade due to the rise of megaconstitutional politics, the mechanisms through which political actors have attempted to achieve constitutional change have, by necessity, shifted. In this light, it is overly simplistic to regard the $S U F A$ as simply a nonconstitutional policy instrument. Rather, it could be seen as an incremental change to the constitutional framework governing federal-provincial relations in the social policy arena.

\section{The Future: SOME PROPOSALS}

Where do we go from here? In my view, the shift from substance to process in the politics of social policy post-Charlottetown is extremely valuable, because it promises to establish a framework for intergovernmental co-operation. Although I think that the federal government enjoys significant amounts of jurisdiction over social policy, and posseses the constitutional authority to act unilaterally in many areas, federal unilateralism is not a viable option in the current political climate. The challenge is to further the project of process, which remains incomplete. An additional move is required - the creation of an institutional architecture to manage intergovernmental relations in the social policy arena. To illustrate how this could happen, consider federal-provincial relations in health care. Joint federal and provincial involvement in health care necessitates institutions to manage that relationship. Indeed, in health care, institutions are absolutely necessary in order to respond to what has become a largely dysfunctional relationship between the federal government and the provinces, by providing a framework within which both sets of governments can manage the system.

In a discussion paper Colleen Flood and I prepared for the Romanow Commission, we proposed the creation of two new institutions. ${ }^{43}$ First, we proposed

42 See Part V of the Constitution Act, 1982, supra note 8. Of course, the courts would be involved in sorting out which amending rule governed a particular proposed amendment.

43 Canada, Royal Commission on the Future of Health Care in Canada, Discussion Paper No. 13 - Strengthening the Foundations: Modernizing the Canada Health Act, by C. Flood 
the establishment of a jointly appointed, non-partisan, and expert Medicare Commission to work with the provinces to establish processes to better satisfy the criteria of comprehensiveness, accessibility, and public governance and accountability (our proposed reworking of public administration). The Commission would reward provinces that meet objective performance indicators or that undertake those reforms that the Commission identifies as worthwhile. To effect real change in the system, the Commission would have to receive a significant sum of federal funds above and beyond existing transfer payments.

Second, we proposed the creation of permanent procedures under the $S U F A$ to deal with disputes over the interpretation of the $C H A$. Such disputes would be heard by specialist panels. Moreover, in addition to being triggered by government complaints, the machinery could also be invoked directly by citizens. Although the federal government would retain the final authority for determining whether to withhold cash payments, dispute settlement machinery would add considerable legitimacy to those decisions, should the federal government abide by panel rulings. The federal government and the provinces apparently agreed on the details of dispute settlement machinery regarding the CHA earlier this year, but those details have not been released to the public.

The Romanow Report, Building on Values, builds on our report by proposing the creation of the Health Council of Canada, and the establishment of a dispute resolution process under the $C H A .^{44}$ Unfortunately, though, the recent First Ministers' Accord on Health Renewal $^{45}$ does not take the institutional agenda seriously enough. Moreover, although it creates a Health Council, it limits the role of that body to monitoring and making annual reports on compliance with the various provisions of the Accord, particularly those that require provincial reporting with respect to performance indicators regarding timely access, quality, sustainability (i.e. health system efficiency and effectiveness), and health status and wellness. On its face, the Accord does not make the Council the forum for federal-provincial co-operation that we had envisioned in our report.

\& S. Choudhry (Ottawa: Queen's Printer, 2002).

${ }_{44}$ Canada, Commission on the Future of Health Care in Canada, Building on Values: The Future of Health Care in Canada Final Report (Ottawa: Queen's Printer, 2002) (Chair: R. Romanow) at 52-59 (Health Council of Canada) and 60 (dispute resolution process).

45 Canada, 2003 First Ministers' Accord on Health Care Renewal (5 February 2003), online: Canadian Intergovernmental Conference Secretariat <www.scics.gc.ca/pdf/ 800039004_e.pdf>.
Moreover, the shift to process suggests a way to bring the courts back into the governance of the Social Union. The key here would be for the courts to acknowledge the constitutional cue contained in the $S U F A$, and to ratify it, analogously to how the courts would enforce amendments to the Constitution achieved through the procedures in Part V of the Constitution Act, 1982. This would entail the courts supervising the procedural norms of the Social Union, while leaving the determination of policy outcomes to governments. An example of how this would work is provided by the CAP Reference. In that case, provinces alleged that the federal government had failed to comply with the terms of agreements signed by each province and the federal government. ${ }^{46}$ Two terms were relevant - that the agreement could only be changed by mutual consent, and that either party could terminate the agreement with one year's notice. Had the Supreme Court enforced either the consent provision or the notice provision, it would not have been setting social policy. Rather, it would have been enforcing terms that encouraged federal-provincial discussions, thereby vindicating the value of process.

The CAP Reference has not been overruled by the Supreme Court. However, it may be time for the Court to revisit that judgment. In addition to the $S U F A$, another cue for change is the Court's judgment in the Secession Reference, ${ }^{47}$ which crafted new constitutional rules governing secession that left the resolution of the terms of secession to the political process, and mandated that parties engage in good faith negotiations to achieve that end. The concern of the Court was with process. And the question that must be asked is whether that concern can be extended beyond the extraordinary context of secession to the everyday, yet vital, aspects of federal-provincial relations that are the lifeblood of the federation.

\section{Sujit Choudhry \\ Faculty of Law, University of Toronto}

An earlier version of this paper was presented at "Constitution and Democracy: Ten Years after the Charlottetown Accord," a conference organized by the Association of Canadian Studies, in Montreal, Quebec, on 26 October 2002. I thank Tsvi Kahana, Ira Parghi, and the conference participants for extremely helpful comments and questions, and Jo-Anne Pickel for excellent research assistance.

\footnotetext{
46 The text of the agreement is reproduced in CAP Reference, supra note 11 at 537-39.
}

${ }^{47}$ Secession Reference, supra note 31. 